\title{
Russia-Saudi Arabia Relations: Geopolitical Rivalry and the Conditions of Pragmatic Rapproachment
}

\author{
Elnur Hasan Mikail, Cavit Emre Aytekin \\ Kafkas University, Kars, Turkey
}

\begin{abstract}
This study examines various aspects of geopolitical rivalry and pragmatic rapproachment moments during the history of relationship between Russia and Saudi Arabia, or the Gulf states in general. In this study, the course of that relationship is considered as the hidden determinative the geopolitical struggles of Middle-East region and also the Russian Middle-East policies. In order to catch the course and progress of Russia-Saudi Arabia relations, this paper includes important historical events related with the Middle-East and Russia's positions in this region occured after the end of the cold war. In this study, the impacts of Russia-Saudi Arabia relationship on the Russian foreign policy and the region are examined through presenting a brief history since the cold war era, and today's conditions especially in current issues such as energy market, oil prices, and the Syria conflict. The main aim of this study was to explain how Russia-Saudi Arabia relations have been affected global-level developments such as the effects of 9/11 attacks, US's war on terror doctrine, Afghanistan and Iraq intervention, the Arab Spring, and the Russian involvement in Syria in September 2015 and what are the conditions of rapproachment and conflict in the dynamic nature of Middle-East politics.
\end{abstract}

Keywords: Russia-Saudi Arabia Relations, Russia's middle east policy, pragmatic geopolitical rivalry, rapproachment

\section{The History and Global Developments}

The relationship between Russia and Saudi Arabia is relatively new phenomenon and can be regarded as unfriendly at the beginning in regional geopolitical basis (Terterov, 2009, p. 156). The important components of that relationship are sometimes based on the Saudi Arabia's support for fundamentalists or jihadists in post-soviet region and as another reality of the Middle-East region and Russian foreign policy, Russia's support to Iran composes the geopolitical rivalry between Russia and Saudi Arabia as major powers in regional/global scope (Nocetti, 2010, p. 4). The tensions caused by differences in ideologies and regional struggle for interest became the main determinant of the relationship between Russia and Saudi Arabia both in Soviet times and in Russia Federation era. However, as global political balance shifts and game-changing developments are happening in Middle-East region, the traditional unfriendly relationship concept between Russia and Saudi

Elnur Hasan Mikail, ass. prof., Department of Political Sciences and International Relations, Faculty of Economics and Administrative Sciences, Kafkas University, Kars, Turkey.

Cavit Emre Aytekin, res. asst., Department of Political Sciences and International Relations, Faculty of Economics and Administrative Sciences, Kafkas University, Kars, Turkey.

Correspondence concerning this article should be addressed to Elnur Hasan Mikail, Department of Political Sciences and International Relations, Faculty of Economics and Administrative Sciences, Kafkas University, Kars, Turkey. 
Arabia faced the possibility of rapproachment especially in 2000s (World Politics Review, n.d.). But that real-political rapproachment possibility does not mean the conventional division issues and rivalry have been overcomed. Russia and Saudi Arabia still remain controversial in some critical issues such as the energy market, the future of Syria, rise of Islamism, etc. So the Russia-Saudi relationship naturally depends on their different interests in the controversial issues as energy market and the dynamic nature of political situation of the Middle-East. Although that is the reality of Russian foreign policy and the Middle-East, Russia aims to reassert its presence in the Arab world by restoring its image and influence in the regional issues through increasing its relations with the Gulf States as major powers of the region (Nocetti, 2010, p. 4).

The relationship is also under the influence of global politics. And after the collapse of the Soviet Union, the first most important global development was the 9/11 attacks in United States. This international-level development became one of the most considerable factors of shaping the Middle-East as a result of the change in US foreign policy concept towards the "War on Terror". Along with the Russia's Western-inclined and non-interventionlist foreign policy concept in the Yeltsin era (Tsygankov, 2010, pp. 58-59), the relationship between Arab World and Russia became considerably declined. However, at the same time, in that unipolar period, Russian foreign policy was dealing with preventing the international terrorism and Islamist fundamentalism to enter the Russia Federation. That was a national security issue for Russia Federation because there was the Islamist and separatist movements that could destabilize the Russian Federation's southern region. Another important matter of international developments for Russia was to maintain and sustain its advantage in main strategic sectors such as energy, oil, fuel, nuclear energy, and arms production.

Another subsequent outcome of the changing global political environment for Russia Federation after the 9/11 attacks and the US's "War on Terror" doctrine is the decline of Americal power and the emergence of rising powers since the beginning of 2000s. That situation, the weakening of American power, and determinance in international level have presented a great opportunity for Russia Federation especially together with the fact that, in Russia, the geopolitical aspirations for reclaimining Russia Federation's super-power status and reasserting political influence of Russia over the Post-Soviet territies became stronger in Russian political scene. Therefore for Russia Federation, increasing the relationship with the ArabWorld, Russia could reach the benefits of weakening of the US's credibility and influence in theregion, and Russia gained a strong opportunity for presenting itself as a counterweight to Western dominated international politics.

Briefly, Russian-Saudi Arabia relations emerged as an opportunity that promises interests for each side. And that increased relationship was parallel with the new orientations of Russian foreign policy which sees the Middle-East as a geopolitical sphere of influence for pusuing the new goals of Russian foreign policy such as reasserting super-power status and confronting the US's unipolarity (Tsygankov, 2010, p. 188). So the possibility of rapprochement between Russia and Saudi Arabia affects some contradictions and limits of Russian policy with regard to the Arab-Muslim world. However, the traditional cooperation between Russia and Iran remains to have priority for Moscow in regional scope. And Russia applies a policy for promoting its interests, which makes the balances of the Middle-East more complex.

\section{Russia-Saudi Arabia Relations After the Cold War}

The position of Gulf Region and the Saudi Arabia in Russian Foreign Policy concept has generally been stable during the cold war. The Cold War Era witnessed an exhibition of mutual opposition and hostility between the USSR-backed actors in Middle East and in the opposite the Saudi-backed actors in South 
Yemen, Iraq, Syria, Ethiopia, Pakistan, and Afghanistan. The Saudi-backed Islamist's insurgency in Afghanistan started in 1979 was one of the most outstanding examples of that confront (Rajan, 2015, p. 190). In that point, the collapse of the USSR produced advantage for the Saudi side as it can use the financial and humanitarian source for encouraging fundamentalists in the Post-Soviet areas and even within the borders of Russia itself, while the oil production and prices in the global market issues continued to be dependent on Saudi Arabia and other gulf states. As the post-cold war times progressed the process of change in Russia-Saudi Arabia relations started in 9/11 was improved after the 2003 Iraq intervention (National Interest, n.d.). The financial effect of that intervention in energy market considerably increased the oil prices (Macleansa, 2014), which has brought important advantages for both Saudi Arabia and Russia and the traditional frictions started to reduce.

That improvements represented pragmatism in Russian foreign policy. In that period, Russian relations with third parties such as Syria and Iran which are relevant with both Russia's and Saudi Arabia's attitutes in the region were not altered. There were also some various controversies in Russia-Saudi Arabia relations. Russia had close relationship with Iraq in Saddam Hussein's era and that reality was declining the possibility of condifence in Russia-Saudi Arabia relationship. And as another fact the weaponry trade between Russia and Iran especially on the sale of missile weapons and nuclear technology and Russia's improved relationship with Israel were main points of Russia-Saudi Arabia incompability (Katz, 2001, p. 617).

INTernational developments and globally increasing demand for energy and rise of prices bring Russia and Saudi Arabia relatively closer, geopolitical realities, and struggle for regional power maximization still in advance within the Russia-Saudi Arabia relations. Russia Federation was facing with the first serious domestic problem after the USSR era, the autonomous republic of Chechnya. Saudi Arabia with the sake of alleged leadership on the Sunni Muslim World, was supporting the separatists in the Russian Autonomous Republic of Chechnya (Katz, 2008, p. 3). This fact completely dismissed any possibilities of cooperation between two sides. Russia regarded Saudi Arabia as supporter of Taliban to harm Russian interests. In addition, Moscow blamed Saudi Arabia for fostering radical Islamism among Muslims in Russia and post-soviet territories. Tensions between the two side increased after Russia's reoccupation of Chechnya in 1999. That reoccupation was seen as inhuman act against Chechnya's Muslims by the Saudi Arabia (Katz, 2008, p. 3). In that fluctuated period, the highest official development in Russia-Saudi relations was the visit of Saudi Prince Abdullah to Moscow in 2003. It was an important attempt for improving Russian-Saudi relationship.

The main factors at the backgroud of that possible reconciliation were primarily the US's intervention in Afghanistan and Iraq based on War on Terror doctrine. Afghanistan and Iraq were the major controversial areas of Russia-Saudi geopolitical rivalry since the cold war. Historically, Saudi Arabie had ties with the Taliban and Russia was supporting Saddam Hussein's regime in Iraq. Another factor was that, since Putin came to power in Russia, the US-Russian relationship started to be strained. And that made Russia to seek alternative actors and openings against US dominance and Western influence in the post-Soviet regions. The Saudi Arabia could present the required alternative for Russian foreign policy. At the beginning of the post-9/11 world, the US-led intervention in Afghanistan was supported by Putin's Russia with the aim of cooperating against international terrorism, Islamist extremism and improving Russia-Western relationship by rendering Washington's regard Moscow as a strategic partner against Chechnya possible. In that period, both United States and Russia Federation were seeing Saudi Arabia as a main source or supporter of Islamist groups. However, Russia's consideration has completely changed after the launch of US intervention in Iraq in 2003. The operation was 
objected by both Moscow and Riyadh, and Putin's Russia started to abandon the Westernist's ideas in foreign policy and became more sceptical about US foreign policy and the Western powers. In that picture, Saudi Arabia became a potential ally against US dominance absolutely with Iran. This process was strenghtened by the increasing strains in the Saudi-US relationship convinced Saudi Arabia on that improving relations with Russia could be useful. Afterwards, in the following years, Russia and Saudi Arabia have improved relations in various realms. And the both sides claimed share the same view terrorism and announced that they would coordinate in counter-terrorism. Thus, the Chechnya's issue was no more the breaker of Russia-Saudi Arabia relations.

In 2007, Russian leader Putin visited Saudi Arabia for the purpose of increasing business relations with Saudi Arabia (Smith, 2007). In 2006, direct flights between Saudi Arabia and Russia were initiated as a representative of improving bilateral relations (Nocetti, 2010, p. 16). Both sides had interest in this process. Russia was in need of foreign investment for sustaining economic growing and stability and Saudi Arabia was looking for protected and stable economic areas in order to make investment. Thus, increased volume of the mutual trade and investment was acceptable for both sides. Russian entrance in the Saudi Arabia's economy is mostly in the energy sector. Mutual accords, agreements, and contracts were signed between Russian and Saudi energy firms in that process (Nocetti, 2010, p. 16). In that economic relationship, Russia was willing to benefit its advantage in weapon and nuclear sectors and tried to sell weapons and nuclear technology to the Saudi Arabia. And for Saudi Arabia, purchasing Russian weapons could be a useful trump against American arms firms which are traditionally selling weapons to the Saudi Arabia. And because the Saudi-Iranian Saudi Arabia was strained to reach nuclear technology, so Russian entrance in Saudi Arabian economy was promising interests for both sides as seen.

The improvement of bilateral relations had impacts on Russian Middle-East politics. Russia attentively tried to protect the balance between its relationship with Iran and Saudi Arabia. Putin's Russia pragmatically attempted to exploit the rivalry between Saudi Arabia and Iran for the purpose of selling arms for both sides. However, Iran was taking assistance from Russia in nuclear energy program and that fact holds the unconfidence in Russia-Saudi Arabia Relations. Another component of contradiction in Russia's Middle-East policies relevant with Saudi Arabia was that Russia's sale of weaponry to Syria which is considered as Iranian proxy power by Saudi Arabia. As Saudi-Syrian relations being deteriorated Russian pragmatic foreign policy continued and led Russia to exploit the rivalry. Actually that times was relatively stable and favourable period in Russia-Saudi Arabia relations compared to the cold war years. However, Russia's changing foreign policy concept in the course of time and rethinking of identity estranged Russia's regional vision in Middle-East. The most important signal was the Arab Awakening started in 2010.

\section{The Arab Spring Period and Russian Involvement in Syria}

Along with the emergence of the Arab Spring, Russia's political influence in the Middle East which was increasingly declining after the collapse of the Soviet Union reduced even further because of the component actors and ideologies of the Arab Spring. Russia at the beginning viewed the process as Western-backed developments for expanding Western influence against Russia Federation's hold in the region. Russian scholars have gone through the "color revolutions" experience in which they blamed Western powers to support the pro-Western movements against post-Soviet governments, so they were sceptical about that kind of popular movements. Thus, the Arab Spring declined Russia's position in the region. 
The Arab Spring process in the Russia's Middle-East politics has shaped the Russia-Saudi Arabia relationship and brought that two powers confronted especially after the Arab Spring spreaded to Syria. In the Syria issue, Russia federation considered the civil commotion as a Western-backed operation against Russia's traditional ally Bashar Al Assad's government. And as the opposition groups in Syria who confronts with the Assad became radicalized the Saudi Arabia and Gulf states' support to anti-Assad groups have appeared. Thus, the fluctuated relationship between Russia and Saudi Arabia became clearly conflictual. As the conflicts continue in Syria among opposition groups, terrorist organizations, and the Syrian government while Russia supports Assad's position in Syria and regards his government as the only legitimate actor, the situation in Syria has not reached a consequence since the beginning of the conflict in 2011, however, Saudi Arabia's position has undergone significant change.

As conflicts continuing in the September 2015, Russia initiated an air campaign in Syria and started a comprehensive intervention in Syria including bombings of the Islamic anti-Assad coalition and the ISIS. As a consequence of the early intervention times, the Sunni front allegedly backed by the Saudi Arabia has weakened. And the Saudi Arabia, therefore forced to reach a compromise in Syrian issue. Russian intervention did not faced with a strong reaction from the Arab League. And Saudi Arabia and Qatar could only do a statement for calling Russia to end its operation against the opposition groups.

The relationship between Russia and Saudi Arabia which is among the most determinant factors in any settlement of the Syrian war, has changed after Russian involvement in Syria and Saudi officials have negotiated with Russian encounters in several times including the purchase of the two former Russian vessels. And Saudi Arabia decided to promise to put $\$ 10$ billion wealth fund into the Russian economy. And weaponry orders of Saudi Arabia from the Russia have come to the agenda.

In that phase, Russia's rapproachment with Saudi Arabia was based on Russia's aim to decline the oil production with Organization of Petroleum Exporting Countries (OPEC) and controll oil prices in global market. The actual matters of Russia-Saudi Arabia relations were about the rise of prices in oil market, selling arms to Saudi Arabia for Russia and to have an influence over the Syrian transition period, and providing alternative cooperation possibility to decline Russia-Iran alliance for the Saudi Arabia.

\section{Conclusion}

The relationship between Russia and Saudi Arabia is traditionally referred with regional geopolitics in the Middle-East since the cold war period. The unfriendly relationship was caused by differences in ideologies and regional struggle for interest and threat perceptions of both side from each other. However, as global political conditions and balances shift with significant events such as 9/11 attacks or the Arab Spring, Russia's foreign policy concept and position in the face of regional countries are being changed. And as a result of that changes, different possibilities in Russia-Saudi Arabia relations gained the possibility of rapproachment in 2000s as seen in this study.

In accordance with the pragmatic foreign policy attitude of Russia Federation in Putin's era, Russia looks for its changing interests in the controversial issues such as energy market and the dynamic nature of political situation of the Middle-East while configuring its Middle-East policy and relationship with Saudi Arabia. Russia aims to reassert its presence in the Arab world, and sometimes pragmatically attempted to exploit the rivalry between Saudi Arabia and Iran for the purpose of selling arms for both sides, configuring oil prices, and confronting the United States in regional issues. 
The most important turning point in recent years in the Russia-Saudi Arabia relationship was the Arab Spring and especially after the Arab Spring spreaded to Syria. As a consequence of the early intervention times, the Sunni front allegedly backed by the Saudi Arabia has weakened across the Russia and the Saudi Arabia, therefore forced to reach a compromise in some disputes. As seen in the study, the actual matters of Russia-Saudi Arabia relations were about the rise of prices in oil market, selling arms to Saudi Arabia for Russia.

\section{References}

Katz, M. (2001). Saudi-Russian Relations in the Putin Era. Middle East Journal, 55/4.

Katz, M. (2008). The Emerging Saudi-Russian Partnership. Mideast Monitor.

Macleans. (2014). Three wars in Iraq and their impact on oil prices. Retrieved from http://www.macleans.ca/economy/economicanalysis/three-wars-in-iraq-and-their-impact-on-oil-prices/

National Interest. (n.d.). Are Saudi-Russian relations fraying? Retrieved from $\mathrm{http}: / /$ nationalinterest.org/feature/are-saudi-russian-relations-fraying-14138

Nocetti, J. (2010). From Moscow to Mecca: Russia's Saudi Arabian Diplomacy. IFRI.

Rajan, V. (2015). Al Qaeda's global crisis: The Islamic state, takfir, and the genocide of Muslims. Routledge.

Smith, M. (2007). Russia and the Persian Gulf the deepening of Moscow's Middle East, policy. Conflict Studies Research Center, August, 7/25.

Terterov, M. (2009). Russian Relations to the Gulf Region in a changing geopolitical environment. Central European Journal of International Security Studies, 3(1).

Tsygankov, A. (2010). Russia's foreign policy change and continuity in national identity (2nd ed.). Lanham, MD: Rowman \& Littlefield.

World Politics Review. (n.d.). Saudi Arabia seeks compromise with Russia Amid Mideast Upheaval. Retrieved from $\mathrm{http} / /$ www.worldpoliticsreview.com/trend-lines/13182/global-insider-saudi-arabia-seeks-compromise-with-russia-amid-mid east-upheaval 